\title{
A postulate for tiger recovery: the case of the Caspian Tiger
}

\author{
C.A. Driscoll ${ }^{1,2}$, I. Chestin ${ }^{3}$, H. Jungius ${ }^{4}$, O. Pereladova ${ }^{5}$, Y. Darman ${ }^{6}$, E. Dinerstein ${ }^{7}$, \\ J. Seidensticker ${ }^{8}$, J. Sanderson ${ }^{9}$, S. Christie ${ }^{10}$, S.J. Luo ${ }^{11}$, M. Shrestha ${ }^{12}$, \\ Y. Zhuravlev ${ }^{13}$, O. Uphyrkina ${ }^{13}$, Y.V. Jhala ${ }^{14}$, S.P. Yadav ${ }^{15}$, D.G. Pikunov ${ }^{16}$, N. Yamaguchi ${ }^{17}$, \\ D.E. Wildt ${ }^{18}$, J.L.D. Smith ${ }^{19}$, L. Marker ${ }^{20}$, P.J. Nyhus ${ }^{21}$, R. Tilson ${ }^{22}$, D.W. Macdonald ${ }^{23}$ \& S.J. O'Brien ${ }^{24}$
}

${ }_{1,23}$ Wildlife Conservation Research Unit, Department of Zoology, University of Oxford, The Recanati-Kaplan Centre, Tubney House, Abingdon Road, Tubney, Oxon OX13 5QL, UK

1,24 Laboratory of Genomic Diversity, National Cancer Institute, Frederick, MD 21702 USA

${ }^{2}$ Present address: WWF Chair in Conservation Genetics at WII Faculty of Wildlife Sciences, Wildlife Institute of India,

Chandrabani, Dehradun, Uttarakhand 248001, India

${ }^{3}$ WWF Russia, Nikoloyamskaya St.,19, bd.3, Moscow, 109240, Russia

${ }^{4}$ WWF International, La Delaissee 13, 1270 Trelex, Switzerland

${ }^{5}$ WWF Russia, Central Asia Programme, Nikoloyamskaya St., 19, bld. 3 Moscow, 109240 Russia

${ }^{6}$ WWF Russia, Amur Branch, Verkhneportovaya St., 18A, Vladivostok, 690003, Russia

${ }^{7}$ WWF US, Conservation Science Program, $125024^{\text {th }}$ St., NW, Washington, DC 20037 USA

${ }^{8}$ Smithsonian Conservation Biology Institute, Conservation Ecology Center, National Zoological Park, Washington, DC, 20013 USA

${ }^{9}$ Wild Cat Research and Conservation Center, Institute for the Environment, University of Arizona, Tucson, Arizona, 85721 USA

${ }^{10}$ Conservation Programmes, The Zoological Society of London, Regents Park, London NW14RY, UK

${ }^{11}$ School of Life Sciences, Peking University, Beijing 100871, China

${ }^{12}$ Save The Tiger Fund, National Fish and Wildlife Foundation, $113315^{\text {th }}$ St., NW, Suite 1100, Washington, DC 20005 USA

${ }^{13}$ Institute of Biology and Soil Science, Russian Academy of Sciences, 159, Prospect 100-letya, Vladivostok 690022 Russia

${ }^{14}$ Wildlife Institute of India, Chandrabani, Dehradun 248001, India

${ }^{15}$ National Tiger Conservation Authority, Ministry of Environment and Forest, Government of India, New Delhi, India

${ }^{16}$ Pacific Institute of Geography, Far East Branch, Russian Academy of Sciences, Radio St. 7, Vladivostok, 690041, Russia

${ }^{17}$ Department of Biological \& Environmental Sciences, University of Qatar, PO Box 2713 Doha, Qatar

${ }^{18}$ Smithsonian Conservation Biology Institute, NZP Conservation and Research Center, Front Royal VA, 22630 USA

${ }^{19}$ Department of Fisheries, Wildlife and Conservation Biology, University of Minnesota, St. Paul, MN 55108, USA

${ }^{20}$ Cheetah Conservation Fund, P.O. Box 1755, Otjiwarongo, Namibia

${ }^{21}$ Environmental Studies Program, Colby College, Waterville, ME, 04901 USA

22 Department of Conservation, Minnesota Zoo, Apple Valley, MN, 55124 USA

Email: ${ }^{1}$ carlos.driscoll@nih.gov (corresponding author), ${ }^{3}$ ichestin@wwf.ru, ${ }^{4}$ hjungius@sunrise.ch, ${ }^{5}$ opereladova@wwf.ru,

${ }^{6}$ ydarman@amur.wwf.ru, ${ }^{7}$ eric.dinerstein@wwfus.org, ${ }^{8}$ seidenstickerj@si.edu, ${ }^{9}$ gato_andino@yahoo.com, ${ }^{10}$ sarah.christie@zsl. org, ${ }^{11}$ luo.shujin@gmail.com, ${ }^{12}$ mahendra.shrestha@nfwf.org, ${ }^{13}$ zhuravlev@ibss.dvo.ru, ${ }^{14}$ jhalay@wii.gov.in, ${ }^{15}$ jdntca@gmail.com, ${ }^{16}$ pikunov-dmitri@yandex.ru, ${ }^{17}$ yamaguchi@qu.edu.qa, ${ }^{18}$ WildtD@si.edu, ${ }^{19} \mathrm{jlds} @ u m n . e d u,{ }^{20}$ cheetah@grumpy.net.na, ${ }^{21}$ pjnyhus@ colby.edu, ${ }^{22}$ ron.tilson@state.mn.us, ${ }^{23}$ David.Macdonald@zoo.ox.ac.uk, ${ }^{24}$ stephen.obrien@nih.gov

Date of publication (online): 26 June 2012 Date of publication (print): 26 June 2012 ISSN 0974-7907 (online) | 0974-7893 (print)

Editor: Mark Stanley Price

Manuscript details:

Ms \# 02993

Received 08 November 2011

Final revised received 23 April 2012

Finally accepted 21 May 2012

Citation: Driscoll, C.A., I. Chestin, H. Jungius, O. Pereladova, Y. Darman, E. Dinerstein, J. Seidensticker, J. Sanderson, S. Christie, S.J. Luo, M. Shrestha, Y. Zhuravlev, O. Uphyrkina, Y.V. Jhala, S.P. Yadav, D.G. Pikunov, N. Yamaguchi, D.E. Wildt, J.L.D. Smith, L. Marker P.J. Nyhus, R. Tilson, D.W. Macdonald \& S.J. O'Brien (2012). A postulate for tiger recovery: the case of the Caspian Tiger. Journal of Threatened Taxa 4(6): 2637-2643.

Copyright, Acknowledgements and Logos: See end of this artilce.

\begin{abstract}
Recent genetic analysis has shown that the extinct Caspian Tiger (P. $t$ virgata) and the living Amur Tigers (P. t. altaica) of the Russian Far East are actually taxonomically synonymous and that Caspian and Amur groups historically formed a single population, only becoming separated within the last 200 years by human agency. A major conservation implication of this finding is that tigers of Amur stock might be reintroduced, not only back into the Koreas and China as is now proposed, but also through vast areas of Central Asia where the Caspian tiger once lived. However, under the current tiger conservation framework the 12 "Caspian Tiger States" are not fully involved in conservation planning. Equal recognition as "Tiger Range States" should be given to the countries where the Caspian tiger once lived and their involvement in tiger conservation planning encouraged. Today, preliminary ecological surveys show that some sparsely populated areas of Central Asia preserve natural habitat suitable for tigers. In depth assessments should be completed in these and other areas of the Caspian range to evaluate the possibility of tiger reintroductions. Because tigers are a charismatic umbrella species, both ecologically and politically, reintroduction to these landscapes would provide an effective conservation framework for the protection of many species in addition to tigers. And for today's Amur Tigers this added range will provide a buffer against further loss of genetic diversity, one which will maintain that diversity in the face of selective pressures that can only be experienced in the wild.
\end{abstract}

Keywords: Caspian Tiger, Central Asia, human conflict, large carnivore, phylogenetic, reintroduction, Tiger Range State. 


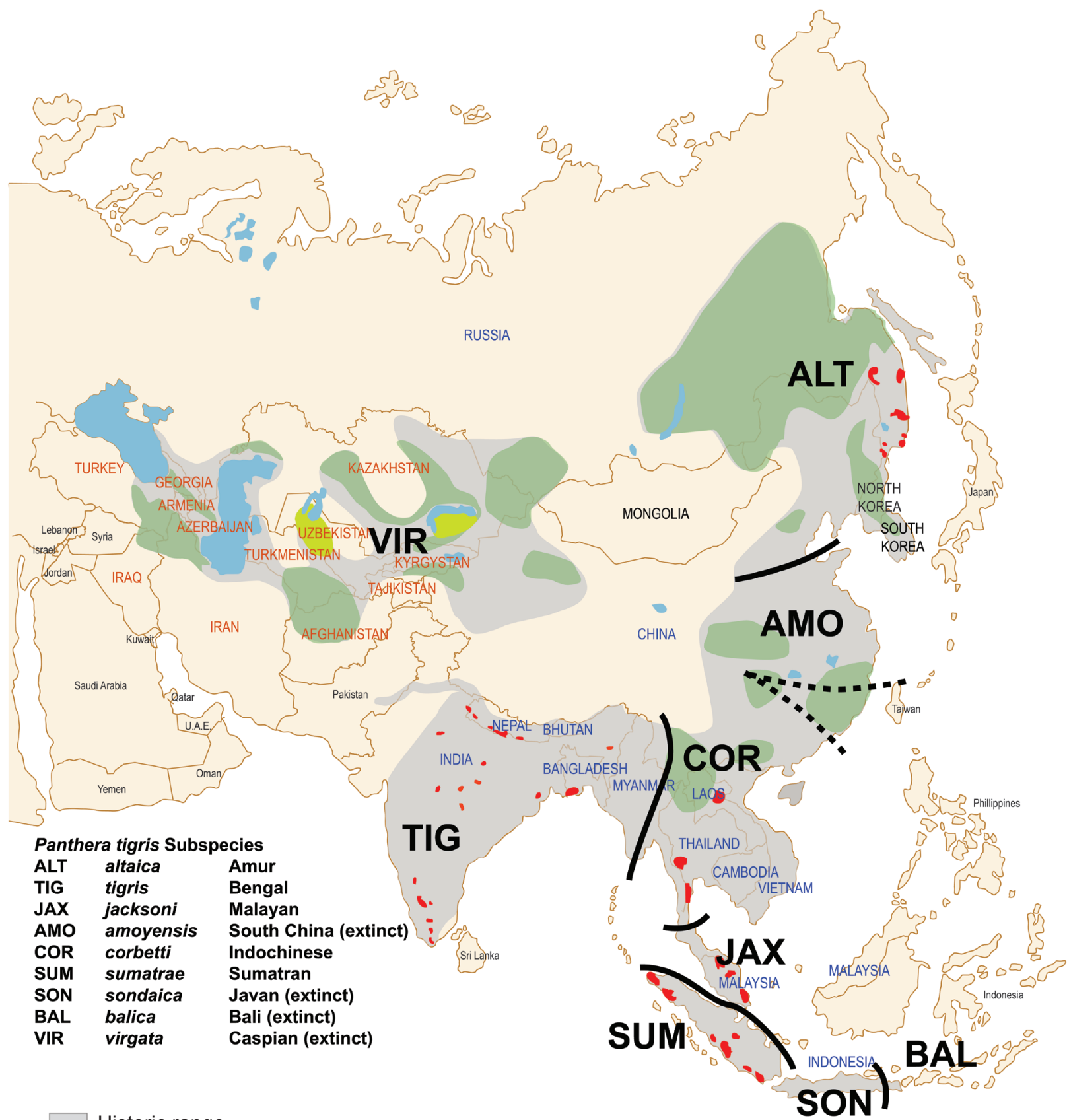

Historic range

Restoration landscapes

Approximate subspecies boundaries

Surveyed high quality habitat

Confirmed tiger presence

Image 1. Map of Tiger Conservation Landscapes

Legend: 'Tiger Range States', countries that show evidence of wild tigers within the last 20 years, are indicated in blue upper case: Bangladesh, Bhutan, Cambodia, China, India, Indonesia, Laos, Malaysia, Burma, Nepal, Russia, Thailand and Vietnam. Central Asian range states of the extinct Caspian tiger in red upper case: Afghanistan, Iraq, Kazakhstan, Turkey, Iran, Tajikistan, Uzbekistan, Turkmenistan, Armenia, Azerbaijan, Georgia, and Kyrgyzstan. In addition Caspian/Amur tigers formerly occurred in the Altai region of Russia, western China, parts of Mongolia, and the Korean peninsula. Caspian tiger historic range, current range and restoration landscape delineations based on Sanderson et al. (2006) and current authors; indicated high quality habitat from detailed feasibility studies in Jungius et al. (2009); Jungius (2010) and Lukarevski \& Baidavletov (2010). 
Another Year of the Tiger has passed and we can say with certainty that global tiger conservation has not succeeded (Walston et al. 2010). Of eight subspecies recognized in the 1930s the Caspian, Javan, Bali and likely the South China tigers have gone extinct despite intense interest in biodiversity conservation, surveillance, legal protection and expenditure. The worldwide population has plummeted from over 100,000 wild tigers a century ago to a paltry 3200 survivors, $\sim 3 \%$ of historical numbers and tigers now inhabit less than $7 \%$ of their historical range (Chundawat et al. 2008; Seidensticker et al. 2010; Tilson \& Nyhus 2010).

From these dire straits, rallying cries have called for doubling the wild tiger population by the next Year of the Tiger in 2022 (Wikramanayake et al. 2009; Hua Hin Declaration on Tiger Conservation 2010; The St. Petersburg Declaration on Tiger Conservation 2010). If tigers are to survive in the wild, much less double in number over the next 10 years, tiger recovery plans will have to deliver more than a simple reinvigoration of on-going conservation programs, and also boldly implement new management initiatives. One such prospect is to restore recently exterminated tiger populations in the former range of the Caspian Tiger (P. t. virgata) (Image 1).

Biologists recently adopted a 'landscape approach' to tiger conservation, which explicitly seeks to identify and preserve all trophic levels naturally present in tiger habitat (Tilson \& Nyhus 2010; Wikramanayake et al. 2011). To this end the 13 currently recognized 'Tiger Range States' (Image 1) have pledged to cooperate in developing and implementing effective tiger conservation plans within their respective boundaries (Hua Hin Declaration on Tiger Conservation 2010). Notably however, of the 13 official 'Tiger Range States' wild tigers are effectively extinct in five: Cambodia, Vietnam, China, Lao PDR and much of Myanmar (Tilson \& Nyhus 2010), though efforts to bolster tiger numbers - including reintroductions - to these regions are ongoing (Global Tiger Recovery Program 2011). Meanwhile, the dozen independent states of Central Asia, which once also supported tigers, are not included in landscape-scale tiger conservation plans, in part because of political infighting in the tiger community. Should not the Central Asian countries in the Caspian Tiger's former range be enlisted in tiger conservation?
In this vast region of central and southwestern Asia, roughly the size of mainland USA, tigers had roamed free until recently; the last Caspian Tiger was shot in Turkey in 1970 (Can 2004). A recent expansive ecological survey of vegetation, available prey, and human footprint (i.e. human population density and infrastructure) reports that over a million square kilometers of potential tiger habitat still exists throughout the former range of the Caspian Tiger (Sanderson et al. 2006; Jungius 2010). Though perhaps only $25 \%$ of the original tiger habitat is potentially suitable for the species today, these 'restoration landscapes' (Sanderson et al. 2006) could be considered in evaluating tiger restoration plans. Though diminished, this area $\left(1,000,000 \mathrm{~km}^{2}\right)$ still amounts to ample habitat for the support of multiple viable tiger populations; three times more land is currently available in the Caspian range than is available in India (Dinerstein et al. 2006; Sanderson et al. 2006), which supports the world's largest population, an estimated 1,700 wild tigers (Jhala et al. 2011). Any restoration plan-in the Caspian range or elsewhere-should in no way detract from current conservation operations for surviving wild tiger populations anywhere else. However, now more than ever, 'business as usual' does not suffice and all logistically feasible and scientifically valid options should be considered for implementation.

Who should be involved and who will benefit from such a plan? Restoration of a historic ecological balance is an explicit goal of the landscape approach to tiger conservation; tiger restoration could thereby provide a conservation impetus and framework for vast areas of natural habitat. Restoration would have several beneficial effects in tiger landscapes, including restoring a quality biologists recognize as 'tigerness'(Wikramanayake et al. 1998) - the suite of ecological, behavioral, and physiological adaptations exhibited by tigers occupying vastly different habitats with different topography, vegetation, prey, diseases and parasites. A reintroduced Caspian tiger population would recover a new dimension of tigerness to Central Asia, encouraging a natural ecological balance by filling a vacant ecological niche at the top trophic level. The need for large areas free of human disturbancewith suitable habitat and prey-implies Caspian Tiger range countries will have to make significant commitments if tiger restoration there is to succeed, 
but they stand to realize equally significant economic and environmental benefits if it does.

Advancing tiger reintroduction should first evaluate the ecological suitability of a proposed site (IUCN 1998; Hayward et al. 2007). In principle, a thorough habitat assessment should reveal a valid way forward, and preliminary steps in this direction have already begun. WWF Russia and WWF Netherlands last year completed on-the-ground feasibility studies (summarized in (Jungius 2010)) based upon historic Caspian tiger range (Heptner \& Sludski 1972) and ecological optima including the human footprint (Krever et al. 1998), in which they identified at least two promising habitats: (1) the Amu-Darya delta and former Aral sea bottomland in Uzbekistan (Jungius et al. 2009) and (2) the South-Balkash/Ily-Delta region in Kazakhstan (Bragin 2010; Lukarevskii \& Baidavletov 2010). Though both regions already have large uninhabited areas and an existing prey base, several measures are needed to better the prospects for sustaining viable tiger populations there. These include implementing protected areas, status, fostering natural habitats, boosting the preferred prey base (Wild Boar and Bukkara Deer, a subspecies of Red Deer), supporting anti-poaching law enforcement, and stabilizing fresh water resources; all this has to be done while ensuring popular local support and government leadership within the host countries.

Which living subspecies should be reintroduced if the Caspian Tiger is extinct, and where are we to get all these tigers? Recent advances in tiger genetics and natural history suggest answers to this question. A DNA-based analysis of museum Caspian Tiger specimens, in the context of their relationship to other tiger subspecies, revealed negligible genetic differences between the Caspian specimens and modern Amur tigers of the Russian Far East (Driscoll et al. 2009). It seems that the Caspian and Amur tigers subspecies were actually a contiguous widespread population until the beginning of the 19th century (Heptner \& Sludski 1972). So the Caspian Tiger is not extinct after all, rather it survives today as the Amur Tiger in the Russian Far East.

Every year, Amur Tigers are removed from the wild in Russia as a result of conflict with humans or orphaning of cubs and so, given appropriate conditioning, many of these cats could be candidates for translocation to Central Asia (Goodrich \& Miquelle
2005). And the Russian Far East is not the only place where the Caspian/Amur Tiger survives; there are over 500 genetically healthy Amur Tigers of known ancestry and relatedness in world zoos (Muller 2009) and the captive population actually carries comparable or higher genetic diversity than the genetically depauperate wild population (Luo et al. 2008; Henry et al. 2009). In addition, a recent genomic technology termed "Verified Subspecies Ancestry" (VSA) has made possible the explicit identification, by a simple DNA test, of individual tigers descending from pure versus admixed subspecies backgrounds (Luo et al. 2008). In principle, captive populations could provide numerous appropriate and healthy founders for decades of tiger restoration (Christie \& Seidensticker 1999; Wildt et al. 2010). Proponents of captive breeding regularly defend that process as an insurance policy against extinction, a backup to in situ conservation of species in the wild (Tilson \& Christie 1999). Here is a real chance to fulfill that potential.

Though reintroducing carnivores, either the translocation of behaviorally competent individuals from the wild or reintroduction from captive sources, is clearly a substantial challenge that should not be underestimated, this proposal is not without precedent. Wolves Canis lupus, Bears Ursus arctos and African Wild Dogs Lycaon pictus all have histories of success (Hayward \& Somers 2009). Felid population restorations have been successful for Lion Panthera leo (Funston 2008), Cheetah Acinonyx jubatus (Pettifer 1981) and Pumas Puma concolor (e.g. Florida Panther) (Johnson et al. 2010), as well as smaller felid species including Iberian Lynx Lynx pardinus (Ruiz et al. 2009), Eurasian Lynx Lynx lynx (von Arx et al. 2009), Canada Lynx Lynx canadensis (Shenk et al. 2009), Bobcat Lynx rufus (Diefenbach et al. 2009) and Wildcat Felis silvestris (Hartmann-Furter 2009). Indian conservationists are actively planning to translocate Asiatic Lions Panthera leo persica from the Gir forest, presently their only home, to secondary sanctuaries within India (Venkataraman 2010) and, further, are negotiating Cheetah reintroductions to India (Ranjitsingh \& Jhala 2010), where they have been extinct for 60 years. Russian authorities are engaged in two leopard restoration programs; one for the Caucasus Leopard Panthera pardus saxicolor (Rozhnov \& Lukarevsky 2008) and one of the Amur Leopard Panthera pardus orientalis) in the Russian 
Far East (Christie 2009).

Limited restorations involving wild-caught tigers have been attempted with varying success in Russia, India and Sumatra (Goodrich \& Miquelle 2005; Check 2006; Johnsingh \& Madhusdan 2009; Gopal et al. 2010; Onishi 2010). In India tigers have been translocated to the Sariska and Panna Tiger Reserves where they went extinct in 2004 and 2008, respectively, due to poaching. Those in Panna have reproduced. These releases involved wild-caught tigers but the release of captive-bred tigers is also being considered. Following exhaustive feasibility studies by government and international wildlife teams over the last 10 years, Chinese authorities are preparing to reintroduce South China Tiger populations to their historic range (Tilson \& Nyhus 2010). And, with ongoing habitat assessments, Iran is evaluating seriously the possibility of restoring tigers, having already secured the first pair from Russia (Anonymous 2010). Furthermore, in a private initiative presented as a proof of concept for the conditioning of captive tigers for life in the wild, four tigers imported from China were introduced to an enclosed 33,000ha habitat in South Africa in 2006 (Save China's Tigers 2010).

Repatriating tigers to areas where they roamed a century ago is ecologically feasible (Seidensticker et al. 1999; Jungius et al. 2009; Jungius 2010) and, if underpinned by good science and planning, requires only national resolve and sound scientific management (IUCN 1987; IUCN/SSC 1998). Reconstituting recently exterminated tiger populations in the Caspian range is not a flight of fancy.

Conservation, while a branch of natural and social science, is also about choices and thus, ultimately, politics; as such it is inevitably controversial and demands wisdom as well as science. The restoration of Caspian Tigers is clearly a big idea, and therefore should advance only with the benefit of the best science and most considered wisdom. We, doubtless, would have preferred to start from a different position, but we are where we are, and eliminating $97 \%$ of the world's tigers in less than a century is already anthropic intervention at its worst. Restoration is not about the nostalgic re-creation of a lost past, but about building a sustainable future (Macdonald 2010). Our suggestion here is not to magically resurrect extinct cats for a Jurassic Park or "Pleistocene re-wilding" experience (Donlan 2005), but rather to restore former tiger landscapes to be as biologically full, diverse, productive and interesting as they once were.

By the Chinese calendar, the Year of the Tiger closed in February 2011. We believe that a new consensus resolution, including the 12 Central Asian countries in the Caspian Tiger's former range, could envision a plan complementary to current tiger conservation strategies that could contribute to the laudable goal of doubling tiger numbers in the wild by 2022, the next Year of the Tiger. Considering the critical state of tiger conservation, time is running out.

\section{REFERENCES}

Anonymous (2010). Iran Recieves Siberian Tigers. Tehran Times, Tehran.

Bragin, E. (2010). Review of the Situation in the Balhash Lake Basin and Water Management Policy of the Ily-Balhash Basin. WWF Russia, 17pp.

Can, O.E. (2004). Status, Conservation and Management of Large Carnivores in Turkey. 24th meeting Standing Committee, Convention on the Conservation of European Wildlife and Natural Habitats. Council of Europe, Strasbourg, France, $27 \mathrm{pp}$.

Check, E. (2006). Conservation biology: the tiger's retreat. Nature 441: 927-930.

Christie, S. (2009). Breeding far eastern leopards for reintroduction: the zoo programme perspective, pp. 462477. In: Vargas, A., C. Breitenmoser \& U. Breitenmoser (eds.). Iberian Lynx Ex Situ Conservation: An Interdisiplinary Approach. Fundacion Biodiversidad, Madrid, Spain.

Christie, S. \& J. Seidensticker (1999). Is reintroduction of captive-bred tigers a feasible option for the future? pp. 207209. In: Seidensticker, J., S. Christie \& P. Jackson (eds.). Riding the Tiger: Tiger Conservation in Human Dominated Landscapes. Cambridge University Press, Cambridge, UK.

Chundawat, R.S., B. Habib, U. Karanth, K. Kawanishi, J.A. Khan, T. Lynam, D. Miquelle, P. Nyhus, Sunarto, R. Tilson \& S. Wang (2011). Panthera Tigris. In: IUCN 2012. IUCN Red List of Threatened Species. Version 2012.1. $<$ www.iucnredlist.org $>$. Downloaded on 23 June 2012.

Diefenbach, D.R., L.A. Hansen, R.J. Warren, M.J. Conroy \& M.G. Nelms (2009). Restoration of Baobcats to Cumberland Island, Georgia, USA: lessons learned and evidence for the role of Bobcats as keystone predators, pp. 422-435. In: Vargas, A., C. Breitenmoser \& U. Breitenmoser (eds.). Iberian Lynx Ex Situ Conservation: An Interdisiplinary Approach. Fundacion Biodiversidad, Madrid, Spain.

Dinerstein, E., C. Loucks, A. Heydlauff, E. Wikramanayake, G. Bryja, J. Forrest, J. Ginsberg, S. Klenzendorf, P. Leimgruber, T. O'Brien, E. Sanderson, J. Seidensticker \& M. Songer (2006). Setting Priorities for the Conservation 
and Recovery of Wild Tigers: 2005-2015. A User's Guide. WWF, WCS, Smithsonian, and NFWF-STF, Washington, D.C.-New York.

Donlan, J. (2005). Re-wilding North America. Nature 436: 913-914.

Driscoll, C.A., N. Yamaguchi, G.K. Bar-Gal, A.L. Roca, S. Luo, D.W. Macdonald \& S.J. O'Brien (2009). Mitochondrial phylogeography illuminates the origin of the extinct Caspian Tiger and its relationship to the Amur Tiger. Plos One 4: e4125.

Funston, P.J. (2008). Conservation and management of lions in southern Africa: status, threats, utilization and the restoration option, pp. 109-131. In: Croes, B., R. Buij, H.H. de Iongh \& H. Bauer (eds.). Management and Conservation of Large Carnivores in West and Central Africa. Institute of Environmental Sciences, Leiden.

Global Tiger Recovery Program (2011). Tiger Range Countries and Global Tiger Iniative. The World Bank, http://www. globaltigerinitiative.org/download/St_Petersburg/GTRP Nov11_Final_Version_Eng.pdf. Downdloaded 23 June 2012.

Goodrich, J.M. \& D.G. Miquelle (2005). Translocation of Probelm Amur Tigers to Alleviate Tiger-Human Conflicts. Oryx 39: 1-4.

Gopal, R.G., Q. Qureshi, M. Bharadwaj, J. Singh \& Y.V. Jhala (2010) Evaluating the status of the endangered Tiger Panthera Tigris and its prey in Panna Tiger Reserve, Madhya Pradesh, India. Oryx 44: 383-389.

Hartmann-Furter, M. (2009). Breeding European Wildcats Felis Silvestris Silvestris, (Schreber 1777) in species-specific enclosures for reintroduction in Germany, pp. 452-461. In: Vargas, A., C. Breitenmoser \& U. Breitenmoser (eds.). Iberian Lynx Ex Situ Conservation: An Interdisiplinary Approach. Fundacion Biodiversidad, Madrid, Spain.

Hayward, M.W., J. O'Brien \& G.I.H. Kerley (2007). Carrying capacity of large African predators: predictions and tests. Biological Conservation 139: 219-229 doi:210.1016/j. biocon.2007.1006.1018

Hayward, M. \& M.J. Somers (2009). Reintroduction of Top-Order Predators. Wiley-Blackwell, Chichester, UK; Hoboken, NJ.

Henry, P., D. Miquelle, T. Sugimoto, D.R. McCullough, A. Caccone \& M.A. Russello (2009). In Situ Population Structure and Ex Situ Representation of the Endangered Amur Tiger. Molecular Ecology 18: 3173-3184.

Heptner, V.G. \& A.A. Sludski (1972). Mammals of the Soviet Union. In: Heptner, V.G. \& N.P. Naumov (eds.). Mammals of the Soviet Union, Carnivora (Hyaenas and Cats). Smithsonian Institution and the National Science Foundation, Washington, D.C., Moscow.

Hua Hin Declaration on Tiger Conservation (2010). First Asia Minesterial Conference on Tiger Conservation (1st AMC), Hua Hin, Thailand. http://www.globaltigerinitiative.org/ download/AMC-declaration-adopted-01-29.pdf.

IUCN (1987). Iucn Position Statement on the Translocation of Living Animals, IUCN, Gland, Switzerland, 13pp.
IUCN/SSC (1998). Guidlines for Reintroductions, IUCN/SSC Reintroduction Specialist Group, Gland, Switzerland, 11pp.

Jhala, Y.V., Q. Qureshi, R. Gopal \& P.R. Sinha (2011). Status of Tigers, Co-predators, and Prey in India, 2010. National Tiger Conservation Authority, Govt. of India, New Delhi, and Wildlife Institute of India, Dehradun, TR 2011/003, 302pp.

Johnsingh, A.J.T. \& M.D. Madhusudan (2009). Tiger reintroduction in India: conservation tool or costly dream? pp. 146-163. In: Hayward, M.W. \& M.J. Somers (eds.). Reintroduction of Top-order Predators. Wiley-Blackwell, Oxford, U.K.

Johnson, W.E., D.P. Onorato, M.E. Roelke, E.D. Land, M. Cunningham, C. Belden, R. McBride, D. Jansen, M. Lotz, D. Shindle, J. Howard, D.E. Wildt, L.M. Penfold, J.A. Hostetler, M.K. Oli \& S.J. O'Brien (2010). Genetic Restoration of the Florida Panther. Science 329: 1641-1645.

Jungius, H. (2010). Feasibility Study on the Possible Reintroduction of the Caspian Tiger in Central Asia. WWF Russia, 36pp. http://assets.panda.org/downloads/final_ tigerreporthartm5_07_2010.pdf.

Jungius, H., Y. Chikin, O. Tsaruk \& O. Pereladova (2009).PreFeasibility Study on the Possible Restoration of the Caspian Tiger in the Amu Darya Delta. WWF Russia, 37pp.http:// www.wwf.ru/data/asia/tiger/tiger_pre-feasibility_study.pdf. Downdloaded 23 June 2012.

Krever, V., O. Pereladova, M. Williams \& H. Jungius (1998). Biodiversity Conservation in Central Asia: An Analysis of Biodiversity and Current Threats and Initial Investment Portfolio. WWF International, Gland, Switzerland, 114pp.

Lukarevskii, V. \& R. Baidavletov (2010). Report on the Field Survey in the Ily River: Investigtions of the Possibilities of Tiger's Presence in the Region and Opportunities for Its Reintroduction. WWF Russia, 9pp. http://www.wwf.ru/data/ asia/tiger/reportily-balhash-_lukr-illustrengl.pdf.

Luo, S.J., W.E. Johnson, J. Martenson, A. Antunes, P. Martelli, O. Uphyrkina, K. Traylor-Holzer, J.L.D. Smith \& S.J. O'Brien (2008). Subspecies genetic assignments of worldwide captive tigers increase conservation value of captive populations. Current Biology 18: 592-596.

Macdonald, D.W. (2010). Lessons learnt and plans laid: severn awkward questions for the future of reintroductions, pp. 411448. In: Hayward, M.W. \& M.J. Somers (eds.). Reintroduction of Top-Order Predators. Wiley-Blackwell, Oxford.

Muller, P. (2009). International Tiger Studbook. Zoologischer Garten Leipzig, Leipzig, Germany, 107pp.

Onishi, N. (2010). Trying to Save Wild Tigers by Rehabilitating Them. New York Times International, New York Times, p.A12 (New York Edition).

Pettifer, H.L. (1981). The experimantal release of captivebred Cheetah into the natural environment, pp. 1001-1024. Chapman, J.A. \& D. Pursley (eds.). Worldwide Furbearer Conference, five. R.R. Donnelley and Sons Co., Falls Church, Virginia.

Ranjitsingh, M.K. \& Y.V. Jhala (2010). Assessing the Potential for Reintroducing the Cheetah in India. Wildlife Trust of India, Noida, \& the Wildlife Institute of India, Dheradun, 
180 pp.

Rozhnov, V.V. \& V.S. Lukarevsky (2008). Program for Reintroduction of Central Asian Leopard in the Caucasus Region. A.N. Severtsov Institute of Ecology and Evolution and Scientific Press Ltd. KMK., Moscow, Russia.

Ruiz, G., M. Lopez, L. Fernandez, J.A. Franco, G. Lopez \& M.A. Simon (2009). Short communication on the first Iberian Lynx translocation from Sierra Morena to the Donana population, pp. 444-451. In: Vargas, A., C. Breitenmoser \& U. Breitenmoser (eds.). Iberian Lynx Ex Situ Conservation: An Interdisiplinary Approach. Fundacion Biodiversidad, Madrid, Spain.

Sanderson, E., J. Forrest, C. Loucks, J. Ginsberg, E. Dinerstein, J. Seidensticker, P. Leimgruber, M. Songer, A. Heydlauff, T. O'Brien, G. Bryja, S. Klenzendorf \& E. Wikramanayake (2006). Setting Priorities for the Conservation and Recovery of Wild Tigers: 2005-2015. The Technical Assessment. WCS, WWF, Smithsonian, and NFWF-STF., New York - Washington, D.C.

Save China's Tigers (2010). Tiger Rewilding. http://english. savechinastigers.org/node/173.

Seidensticker, J., B. Gratwicke \& M. Shrestha (2010). How Many Wild Tigers Are There? An Estimate for 2008, pp. 295-299. In: Tilson, R. \& P. Nyhus (eds.). Tigers of the World: The Science, Politics, and Conservation of Panthera Tigris. Elsevier, Amsterdam.

Seidensticker, J., P. Jackson \& S. Christie (1999). Riding the Tiger: Tiger Conservation in Human-Dominated Landscapes, Zoological Society of London; Cambridge University Press, Cambridge; New York.

Shenk, T.M., R.H. Kahn, G. Byrne, D. Kevin, S. Wait, J. Seidel \& J. Mumma (2009). Canada Lynx (Lynx Canadensis) reintroduction in Colorado, pp. 410-421. In: Vargas, A., C. Breitenmoser \& U. Breitenmoser (eds.). Iberian Lynx Ex Situ Conservation: An Interdisiplinary Approach. Fundacion Biodiversidad, Madrid, Spain.

The St. Petersburg Declaration on Tiger Conservation (2010). The International Forum on Tiger Conservation, Saint Petersburg, Russia. http://www.globaltigerinitiative. org/wp-content/uploads/2010/06/Declaration-on-TigerConservation-NEGOTIATED-DRAFT-14July2010.pdf

Tilson, R. \& S. Christie (1999). Effective Tiger Conservation Requires Cooperation: Zoos as a Support for Wild Tigers, pp. 200-214. In: Seidensticker, J., S. Christie \& P. Jackson (eds.). Riding the Tiger: Tiger Conservation in A Human-Dominated Landscape. Cambridge Universtity Press, Cambridge, UK.

Tilson, R.L. \& P.J. Nyhus (2010). Tigers of the World: The Science, Politics, and Conservation of Panthera Tigris. Elsevier, Ammsterdam, 524pp.

Venkataraman, M. (2010) 'Site'ing the Right Reasons: Critical Evaluation of Conservation Planning for the Asiatic Lion. European Journal of Wildlife Research 56: 209-213.

von Arx, M., C. Breitenmoser-Wursten \& U. Breitenmoser (2009) Lessons from the reintroduction of the Eurasian Lynx in Central and West Europe, pp. 403-409. In: Vargas, A., C. Breitenmoser \& U. Breitenmoser (eds.). Iberian Lynx Ex
Situ Conservation: An Interdisiplinary Approach. Fundacion Biodiversidad, Madrid, Spain.

Walston, J., J.G. Robinson, E.L. Bennett, U. Breitenmoser, G.A. da Fonseca, J. Goodrich, M. Gumal, L. Hunter, A. Johnson, K.U. Karanth, N. Leader-Williams, K. Mackinnon, D. Miquelle, A. Pattanavibool, C. Poole, A. Rabinowitz, J.L. Smith, E.J. Stokes, S.N. Stuart, C. Vongkhamheng \& H. Wibisono (2010) Bringing the Tiger Back from the Brink-the Six Percent Solution. PLoS Biol 8.

Wikramanayake, E., S. Lieberman, P. Nihan \& J. Benn (2009). Tigers Alive! Saving Tigers in the Wild. Strategic Plan 2010-2015. World Wildlife Fund for Nature, Washington, D.C., 93pp.

Wikramanayake, E.D., E. Dinerstein, J.G. Robinson, U. Karanth, A. Rabinowitz, D. Olson, T. Mathew, P. Hedao, M. Conner, G. Hemley \& D. Bolze (1998). An ecologybased method for defining priorities for large mammal conservation: the tiger as case study. Conservation Biology 12: 865-878.

Wikramanayake, E., E. Dinerstein, J. Seidensticker, S. Lumpkin, B. Pandav, M. Shrestha, H. Mishra, J. Ballou, A.J.T. Johnsingh, I. Chestin, S. Sunarto, P. Thinley, K. Thapa, G. Jiang, S. Elagupillay, H. Kafley, N.M.B. Pradhan, S. Teak, K. Jigme, P. Cutter, M.A. Aziz, and U. Than (2011). A landscape-based conservation strategy to double the wild tiger population. Conservation Letters 4 : 219-227. doi: 10.111/j.1755-263X.2010.00162.x

Wildt, D., W. Swanson, J. Brown, A. Sliwa \& A. Vargas (2010). Felids ex situ: managed programmes, research, and species recovery, pp. 217-235. In: Macdonald, D.W. \& A.J. Loveridge (eds.). Biology and Conservation of Wild Felids. Oxford University Press, Oxford, UK.

Copyright: (C C.A. Driscoll, I. Chestin, H. Jungius, O. Pereladova, Y. Darman, E. Dinerstein, J. Seidensticker, J. Sanderson, S. Christie, S.J. Luo, M. Shrestha, Y. Zhuravlev, O. Uphyrkina, Y.V. Jhala, S.P. Yadav, D.G. Pikunov, N. Yamaguchi, D.E. Wildt, J.L.D. Smith, L. Marker, P.J. Nyhus, R. Tilson, D.W. Macdonald \& S.J. O'Brien 2012. Creative Commons Attribution 3.0 Unported License. JoTT allows unrestricted use of this article in any medium for non-profit purposes, reproduction and distribution by providing adequate credit to the authors and the source of publication.

Acknowledgements: We thank Urs Breitenmoser, Christine BreitenmoserWursten, Dale Miquelle, Eric Sanderson and John Goodrich for helpful comments on an earlier draft of this manuscript.

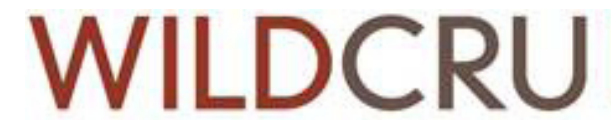

Wildlife Conservation Research Unit

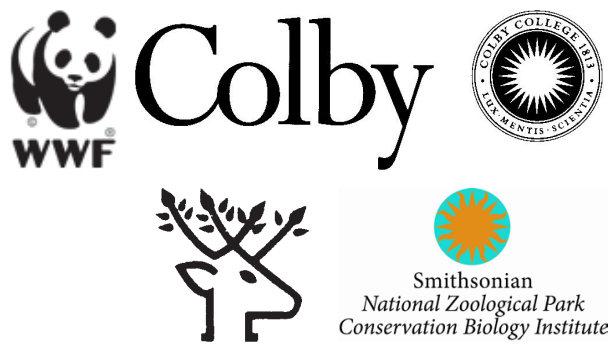

